\title{
Nuevos materiales absorbentes acústicos obtenidos a partir de restos de botellas de plástico
}

\section{New absorbent acoustic materials from plastic bottle remnants}

\author{
R. del Rey ${ }^{(*)}$, J. Alba(*), J. Ramis ${ }^{(* *)}$, V. J. Sanchís ${ }^{(*)}$
}

Recepción/Received: 13-V-10 Aceptación/Accepted: 03-IX-10

\section{RESUMEN}

En el ámbito de acústica de la edificación es común el uso de materiales fibrosos como materiales absorbentes acústicos. Uno de estos materiales cada vez más utilizado es la lana de poliéster. Un problema que presenta el chip virgen de poliéster es que se obtiene del petróleo, cuyo precio no hace más que incrementarse en los últimos años. En este trabajo se presenta una lana de poliéster alternativa, obtenida mediante el tratamiento del PET, a través del conveniente ciclo de reciclado de botellas de plástico. Se comparan valores del coeficiente de absorción; en incidencia normal y en cámara reverberante de los materiales elaborados a partir de chip virgen y de las nuevas lanas obtenidas del PET. Además, se propone un modelo empírico de comportamiento acústico de estas nuevas lanas. Los resultados obtenidos han sido favorables, la fibra virgen ya ha sido sustituida por fibra reciclada en su proceso de fabricación.

Palabras clave: absorción acústica, absorbentes textiles, nuevos materiales, resistencia al flujo, fibras recicladas.

\section{SUMMARY}

In the building acoustics field usually fibrous materials are used as sound absorbing materials. Nowadays polyester fiber is one of the most used but the pure chip of polyester has a problem. Polyester is obtained of petroleum and its price was increasing last years. This paper, presents an alternative polyester wool which obtained by PET treatment (recycle of plastic bottle's). Absorption coefficient values at normal incidence measured in reverberation chamber were compared (new wool obtained by PET method and materials obtained from pure chip of polyester). Furthermore, this paper propound a empiric model that describe the acoustic performance of this new wool. The results have been good. The pure fiber has been replaced by recycle fiber in its manufacture process.

Keywords: sound absorption, textile absorbent, new materials, airflow resistivity, recycled fibre.

\footnotetext{
(*) Universidad Politécnica de Valencia, Campus Gandía (Valencia, España).

(**) Universidad de Alicante (Alicante, España).
} 


\section{INTRODUCCIÓN}

En el ámbito de acústica de la edificación ya es habitual el uso de materiales acústicos absorbentes basados en materiales fibrosos. Existen diferentes soluciones constructivas probadas en obra tanto para aislar como acondicionar acústicamente $(1,2)$. Además, estas fibras forman parte ya del Catálogo de Elementos Constructivos (CEC), documento reconocido que acompaña al Documento Básico de Protección Frente al Ruido (DB-HR) del Código Técnico de la Edificación (CTE) (3).

Estos materiales presentan ciertas ventajas: algunos son hipoalergénicos, lo que facilita su instalación, son lavables, pueden provenir del reciclado, y la aplicación de fibras técnicas permite el cumplimiento de la normativa contra el fuego; CERTIFICADO EUROCLASES (Instituto Tecnológico del Textil, AITEX, No Ensayo: 2007 AN7105 según norma UNE EN ISO 11925-2:2002 y UNE EN 13823:2002). El producto no es combustible ni sus humos son tóxicos por inhalación, según la exigencia de CTE.

El uso de estos materiales también se ha extendido a otros ámbitos como el diseño de recintos acústicos (material absorbente en el interior de cajas de altavoces) (4) o en su uso conducciones de aire acondicionado (5).

En la gran mayoría de soluciones que se presentan en las referencias citadas hasta el momento, los materiales textiles utilizados son elaborados a partir de fibras de poliéster. La lana de poliéster presenta todas las ventajas anteriormente citadas, y es fácilmente comprobable su aplicabilidad en diferentes ámbitos del acondicionamiento o aislamiento acústico. Uno de los problemas que presenta actualmente la lana de poliéster es que su fibra se obtiene del petróleo, cuyo precio no hace más que incrementarse en los últimos años. Dado que existen empresas relacionadas con el textil con líneas de fabricación basadas en gran parte con fibra de poliéster, es sensato el buscar nuevas fibras parecidas o idénticas, que provengan del reciclado. Es por ello por lo que se piensa en las fibras del reciclado de botellas de plástico para elaborar nuevos materiales absorbentes acústicos. Ya se viene trabajando desde hace tiempo en la línea del reciclado y del uso de las fibras naturales, como demuestra un trabajo detallado sobre el Kenaf que se usa como base de un material absorbente acústico (6).

Para validar el uso de nuevas fibras de PET en la fabricación de lanas, se comparan los resultados obtenidos con las nuevas lanas, respecto a las obtenidas con el chip virgen del petróleo, utilizando el mismo proceso de fabricación industrial, sin modificaciones.

Se ha medido el coeficiente de absorción en incidencia normal de múltiples muestras para valorar el comportamiento

\section{INTRODUCTION}

In the field of acoustics in building the use of acoustic absorbent materials prepared from fibrous materials is common. There are different construction solutions tested in building for insulating as well as for acoustic conditioning $(1,2)$. Moreover, these fibres already belong to the Catalog of Building Solutions (CEC), recognised document that comes along with the Basic Document HR- DB Protection Against Noise of the Technical Building Code (CTE) (3).

These materials have some advantages: some are hipoallergenic, what eases its installation, they are washable, they may come from recycling, ad the application of technical fibres allows the fulfilment of the law against fire; EUROCLASS CERTIFICATE (Instituto Tecnológico del Textil, AITEX, Test no.: $2007 A N 7105$ according to the law UNE EN ISO 11925-2:2002 and UNE EN 13823:2002). The product is not combustible and its fumes are not toxic by inhalation, according to the requirement of the CTE.

The use of these products has been extended to other fields such as the design of acoustic precincts (absorbent material inside speakers boxes) (4) or its use in air conditioning conductions (5).

In most of the solutions presented in the references mentioned before the textile materials used are manufactured from polyester fibres. Polyester wool has all the advantages introduced before and it is easy to check its applicability in different contexts of the acoustic conditioning or insulation. One of the problems polyester wool has today is its fibre is made out of oil, whose price is increasing more and more in the recent years. Since there are companies related to the textile that include the polyester fibre in the manufacture processes, it is sensible to look for other new fibres, similar or different, that come from recycling. This is the reason for choosing the fibres from the recycling of plastic bottles to make new absorbent acoustic materials. There has already been conducted a research on this recycling and use of natural fibres previously, as it shows the thorough work on Kenaf as a base for an absorbent acoustic material (6).

In order to validate the use of new PET fibres in the manufacture of wool, the results obtained from the new wool are compared to the ones achieved with the pure oil chip, by using the same industrial manufacturing process, without modifications.

The absorption coefficient in normal incidence for multiple samples has been measured to assess the 
acústico de las muestras elaboradas a partir de PET reciclado, y se han comparado con las muestras originales. Estas mediciones se utilizan como indicador comparativo del comportamiento acústico, como aparece ya en varias referencias (7-9). También se ha medido el coeficiente de absorción en cámara reverberante, y se ha proyectado un modelo semi-empírico del modelado del comportamiento acústico de las lanas basadas en el PET reciclado (6).

\section{FABRICACIÓN DE LANAS}

Una ventaja importante de este desarrollo es que la maquinaria utilizada para la elaboración de las lanas de poliéster a partir de chip virgen de poliéster es la misma, sin modificaciones, que obtiene las basadas en los copos de reciclado de botellas de plástico. El proceso de fabricación de las lanas de poliéster es como un no tejido, vía seca y por termo-fusión. La fibra de poliéster de origen "se peina" y se introduce en la maquinaria. La caula acaba generando lanas de poliéster mediante termo-fusión (la fibra funde a $140-150^{\circ} \mathrm{C}$ ) comprimiendo el material a la densidad deseada en función de la capacidad de la maquinaria. La misma operación se realiza con la fibra obtenida de los copos de PET reciclado. En ambos procesos de fabricación la materia prima pasa por una fase de limpieza, para evitar impurezas, posteriormente es introducida en un horno donde se produce la termofusión. El poliéster, virgen o reciclado, pasa a formar placas de longitud, espesor y densidad deseadas para poder ser colocado de manera más sencilla como material absorbente, después de pasar los controles de calidad. En la Figura 1 se puede observar los copos de plástico antes de pasar por la cadena de fabricación y una imagen de microscopio de las fibras de poliéster. acoustic behaviour of the samples made out of recycled $P E T$, and have been compared to the original ones. These measurements are used as a comparative indicator of the acoustic behaviour, as it appears in some references (7-9). The absorption coefficient has also been measured in a reverberation room, and it's been planned a semi-empirical model of the acoustic behaviour modelling of the recycled PET-based wool (6).

\section{WOOL MANUFACTURING PROCESS}

An important advantage of these developments is the machinery used for the manufacture of the polyester wool from pure polyester chip of the wool itself, without modifications since it gets the wool from the recycled plastic bottle flakes. The manufacturing process of the polyester wool is like a not-woven, dry process and by thermo fusion. The polyester fiber "is combed" and put in the machine. The caula ends up generating polyester wool by thermo fusión (fiber melts at $140-150^{\circ} \mathrm{C}$ ) compressing the material to the desired density depending on the capacity of the machine. The same process is done with the fibre from the recycled PET flakes. In both processes of manufacture raw material is first cleaned to eliminate impurities and later it is put into an oven where thermo fusion takes place. Polyester, whether pure or recycled, turns into layers with the expected length, thickness and density to be easily placed as an absorbent material, after passing the quality tests. In Figure 1 we can observe the plastic flakes before the manufacture process and a microscope image of the polyester fibers.

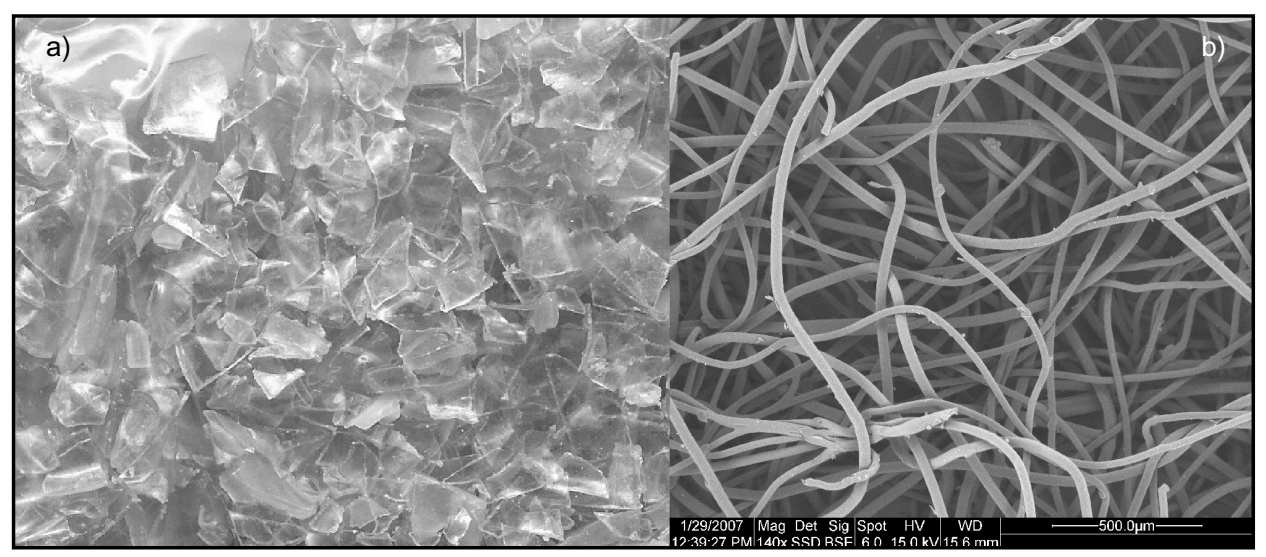

Figura 1. a) Copos de reciclado PET. b) Imágenes de microscopio de fibras de poliéster. Figure 1. a) Recycled PET flakes. b) Microscope figure of polyester fiber. 


\section{PROGRAMA EXPERIMENTAL Y MODELO SEMI-EMPÍRICO}

En este apartado se repasan los procedimientos necesarios para la caracterización acústica de las lanas fabricadas.

\subsection{Coeficiente de absorción en incidencia normal y resistencia al flujo}

Para obtener el coeficiente de absorción en incidencia normal, se ha aplicado el método de la función de transferencia descrito en la norma UNE-EN ISO 10534-2:2002 (10).

La resistencia al flujo del material, se ha determinado experimentalmente en laboratorio utilizando el método de Ingard\&Dear (11), que constituye una alternativa ventajosa a la Norma UNE-EN 29053:1994 (12). El procedimiento experimental utilizado se describe de forma detallada en (6).

Los ensayos de coeficiente de absorción en incidencia normal y de la resistencia al flujo han sido realizados en el laboratorio de acústica de la Escuela Politécnica Superior de Gandía de la Universidad Politécnica de Valencia.

\subsection{Coeficiente de absorción en cámara reverberante}

Los ensayos del coeficiente de absorción sonora de ambos tipos de lanas se han realizado según el procedimiento de medida detallado en la norma UNE-EN ISO 354:2004 (13). En esta normativa se describe un método de medición del coeficiente de absorción sonora de materiales acústicos empleados como tratamiento de paredes y techos. Los resultados obtenidos, cita la norma, pueden emplearse con fines comparativos y de diseño.

Los ensayos han sido realizados en la cámara reverberante sita en la Escuela Politécnica Superior de Gandía de la Universidad Politécnica de Valencia. Esta cámara cumple con las características de volumen y forma especificadas en (13), asegurando así las condiciones de campo difuso. En la Figura 2 se pueden observar algunos de los

\section{EXPERIMENTAL PROGRAMME AND SEMI-EMPIRICAL MODEL}

In this section we revise the necessary procedure for the acoustic characterisation of the manufatured wool.

\subsection{Absorption coefficient in normal incidence and airflow resistivity}

In order to get the absorption coefficient in normal incidence, it has been applied the transfer function method described in the standard UNE-EN ISO 10534-2:2002 (10).

The airflow resistivity of material has been established experimentally in a laboratory by using the Ingard\&Dear method (11), which is an advantageous alternative to the Standard UNE-EN 29053:1994 (12). The experimental procedure used is described in detail in (6).

The tests on the absorption coefficient in normal incidence and on the airflow resistivity have been carried out in the acoustics laboratory of the Higher Polytechnical School of Gandía of the Polytechnical University of Valencia.

\subsection{Absorption coefficient in a reverberation room}

The tests on the sound absorption coefficients of both kinds of wool have been made according to the measurement procedure in the standard UNE-EN ISO 354:2004 (13). In this it is described a method for the measurements of the sound absorption coefficient of acoustic materials used in walls and roofs. The results, says the standard, can be used for comparative and design purposes.

The tests have been carried out in the reverberation room located in the Higher Polytechnical School of Gandía of the Polytechnical University of Valencia. This room fulfills the requirements of volume and shape specified in (13), making sure the conditions of the diffuse field. In Figure 2 it can be seen some of the tests

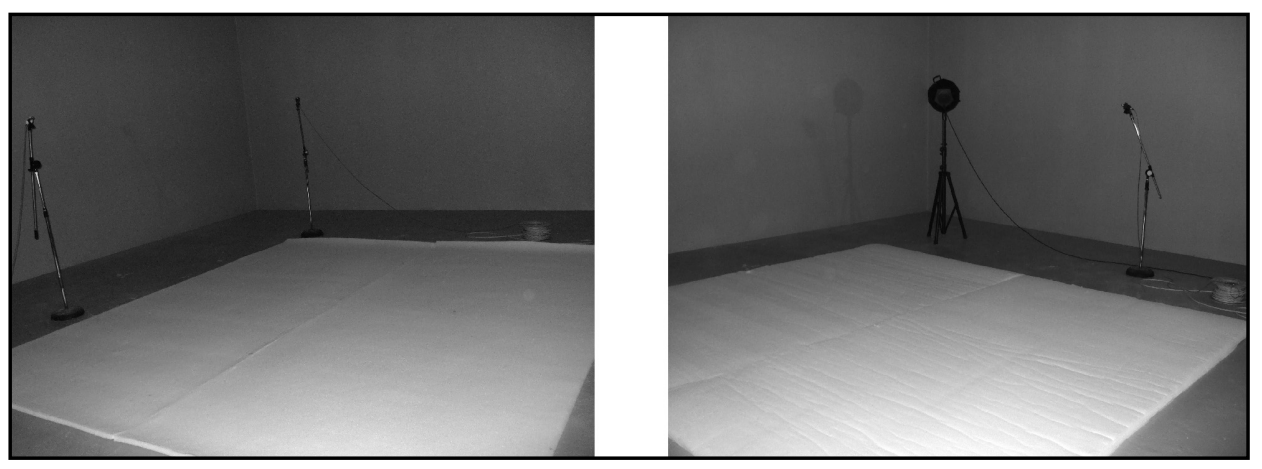

Figura 2. Ensayos realizados en cámara reverberante. Figure 2. Tests in a reverberation room. 
ensayos realizados en la cámara reverberante de la Escuela Politécnica Superior de Gandía.

\subsection{Modelo semi-empírico}

El modelo semi-empírico que reproducimos en este trabajo pretende describir el comportamiento acústico de un material fibroso utilizando el menor número posible de parámetros físicos no intrínsecos, atenuando de esta forma algunos errores de propagación que se cometen al utilizar parámetros obtenidos experimentalmente para implementar modelos empíricos. Este modelo se detalla en (6) para describir el comportamiento de un material fibroso elaborado a partir de fibras naturales y se basa en trabajos ya consolidados (14-17) que describen el comportamiento acústico de los mismos desde el punto de vista frecuencial.

Básicamente, se trata de encontrar los coeficientes $\mathrm{Ci}$ $(i=1 \ldots 8)$ que mejor ajusten las siguientes ecuaciones [1] [2] [3] y [4]: done in the reverberation room of the Higher Polytechnical School of Gandía.

\subsection{Semi-empirical model}

The semi-empirical model that we reproduce in this work intends to describe the acoustic behaviour of a fibrous material using fewer number of non-intrinsic physical parameters, reducing the error propagation when using parameters experimentally achieved to implement empirical models. This model is detailed in (6) to describe the behaviour of a fibrous material from natural fibres and it is based on consolidated works (14-17) which describe their acoustic behaviour from the frequency point of view.

Basically, it is to do with finding the coefficients $\mathrm{Ci}$ (i=1...8) that fit the following equations best [1] [2] [3] $y[4]:$

$$
\begin{gathered}
\alpha=\left(\frac{2 \times \pi \times f}{C_{0}}\right) \times\left[C_{5} \times\left(\frac{\rho_{0} \times f}{r}\right)^{-C_{6}}\right] \\
\beta=\left(\frac{2 \times \pi \times f}{C_{0}}\right) \times\left[1+C_{7} \times\left(\frac{\rho_{0} \times f}{r}\right)^{-C_{8}}\right] \\
Z_{R}=\rho_{0} \times C_{0}\left[1+C_{1} \times\left(\frac{\rho_{0} \times f}{r}\right)^{-C_{2}}\right] \\
Z_{I}=-\rho_{0} \times C_{0}\left[C_{3} \times\left(\frac{\rho_{0} \times f}{r}\right)^{-C_{4}}\right]
\end{gathered}
$$

Donde $\alpha$ y $\beta$ son la parte real e imaginaria de la constante de propagación del material, $Z_{R}$ y $Z_{I}$ son la parte real e imaginaria de la impedancia característica normalizada y $r$ la resistencia al flujo en $\left(N \times s / \mathrm{m}^{4}\right), \rho_{0}$ es la densidad del aire $\left(\approx 1,2 \mathrm{~kg} / \mathrm{m}^{3}\right), f$ la frecuencia $(\mathrm{Hz})$ y $\mathrm{c}_{0}$ es la velocidad del sonido en el aire $(\approx 343 \mathrm{~m} / \mathrm{s})$.

Además, para obtener el coeficiente de absorción a partir de la constante de propagación y la impedancia descrita en (18) utilizamos la siguiente expresión [5]:
Where $\alpha$ y $\beta$ are the real and imaginary part of the propagation constant of the material, $Z_{R} y Z_{I}$ are the real and imaginary of the normalised impedance and $r$ the airflow resistivity in $\left(N \times s / m^{4}\right), \rho_{0}$ is the air density $\left(\approx 1.2 \mathrm{~kg} / \mathrm{m}^{3}\right), f$ is the frequency $(\mathrm{Hz})$ and $c_{0}$ is the sound speed in the air $(\approx 343 \mathrm{~m} / \mathrm{s})$.

Furthermore, in order to obtain the absorption coefficient, the propagation constant and the impedance described in (18) we use the following expression [5]:

$$
\alpha_{n}=\frac{4 \cdot Z_{I} \cdot \rho_{0} \cdot c_{0}}{\left|Z_{l}\right|+2 \cdot \rho_{0} \cdot c_{0} \cdot Z_{I R}+\left(\rho_{0} \cdot c_{0}\right)^{2}}
$$

Siendo I el espesor de la muestra y la expresión para la impedancia de cierre [6]:
Being I the thickness of the sample and the expression for the closing impedance [6]:

$$
Z_{I}=\left(Z_{R}+j \times Z_{I}\right) \times[\cot (\alpha+j \times \beta) \times l]
$$


Para llevar a cabo el ajuste, es necesario, disponer de datos del coeficiente de absorción en incidencia normal y de resistencia al flujo del material en cuestión.

Para obtener los coeficientes que describen de mejor forma el comportamiento acústico medido de las muestras de reciclado de $\mathrm{PET}$, se ha utilizado un método iterativo de disminución de función de error cuadrática. La función de error cuadrática del método iterativo utilizado, se define de la siguiente forma [7]:
In order to fit the equation, it is necessary to have the data of the absorption coefficient in normal incidence and of the airflow resistivity of the material under assessment.

In order to obtain the coefficients that describe best the measured acoustic behaviour of the recycled PET samples, a decreasing iterative method of quadratic error function. The quadratic error function of the iterative method used is described as follows [7]:

$$
\varepsilon=\sum_{i=1}^{N}\left(\alpha_{n, i}-\hat{\alpha}_{n, i}\right)^{2}
$$

donde $\alpha_{n, i}$ representa el valor del coeficiente de absorción en incidencia normal, medido para un material absorbente elegido, a la frecuencia i-ésima y $\hat{\alpha}_{n, i}$ es la estimación del valor anterior realizada a partir de las ecuaciones [1] a [4]. Para la minimización de la función de error es necesario igualar a cero la siguiente expresión [8]: where $\alpha_{n, i}$ stands for the value of the absorption coefficient in normal incidence, measured for a chosen absorbent material, at the ith frequency and $\hat{\alpha}_{n, i}$ is the previous estimation of the value obtained from the equations [1] to [4]. In order to minimise the error function it is necessary to equal to zero the following expression [8]:

$$
\frac{\partial \varepsilon}{\partial A_{i}}=2 \sum_{i=1}^{N}\left(\alpha_{n, i}-\hat{\alpha}_{n, i}\right) \frac{\partial \hat{\alpha}_{n, i}}{\partial A_{i}}=0 \quad i=1, \ldots 8
$$

\section{RESULTADOS}

\subsection{Coeficiente de absorción en incidencia normal y resistencia al flujo}

En la Tabla 1 se enumeran algunas de las muestras de lanas a partir de reciclado ensayadas y algunas de sus características básicas, como densidades, espesor y valores de la resistencia específica al flujo, obtenidas según el procedimiento descrito en el apartado 3.

\section{RESULTS}

\subsection{Absorption coefficient in normal incidence and flow resistance}

In Table 1 some of the wool samples from the recycled tested are listed, as well as some of their basic characteristics such as density, thickness and flow resistance values obtained following the process described in section 3.

Tabla 1 / Table 1

Valores de espesor, densidad y resistencia específica al flujo de algunas de las muestras ensayadas. Thickness, density and flow resistance values of some of the samples tested.

\begin{tabular}{|c|c|c|c|}
\hline Nombre / Name & $\begin{array}{c}\text { Espesor }(\mathbf{m m}) \text { / } \\
\text { Nominal thickness }(\mathbf{m m})\end{array}$ & $\begin{array}{c}\text { Densidad }\left(\mathbf{g} / \mathbf{m}^{2}\right) / \\
\text { Bulk density }\left(\mathbf{g} / \mathbf{m}^{2}\right)\end{array}$ & $\begin{array}{c}\text { Resistencia específica al flujo }\left(\mathbf{k p a s} / \mathbf{m}^{2}\right) / \\
\text { Airflow resistivity }\left(\mathbf{k p a s} / \mathbf{m}^{2}\right)\end{array}$ \\
\hline $1400-4$ & 40 & 1400 & 3.8 \\
\hline $1200-2$ & 20 & 1200 & 3.8 \\
\hline $1000-4$ & 40 & 1000 & 3.5 \\
\hline $800-4$ & 40 & 800 & 2.1 \\
\hline $500-2$ & 20 & 500 & 2.8 \\
\hline $400-4$ & 40 & 400 & 1.5 \\
\hline
\end{tabular}

En las Figuras 3, 4 y 5 podemos observar los valores del coeficiente de absorción en incidencia normal en función de la frecuencia para las diferentes muestras de lanas fabricadas con fibras de reciclado PET, lanas de poliéster con chip virgen y la comparación entre ambas, respectivamente.
In Figures 3, 4 and 5 we can observe the values of the absorption coefficient in normal incidence depending on the frequency for the different wool samples manufactured with PET recycled fibres, pure chip wool and the comparison between them, respectively. 
UNE en ISO 10534-2:2002. Evolución lanas recicladas / UNE en ISO 10534-2:2002. Recycled Wool Evolution

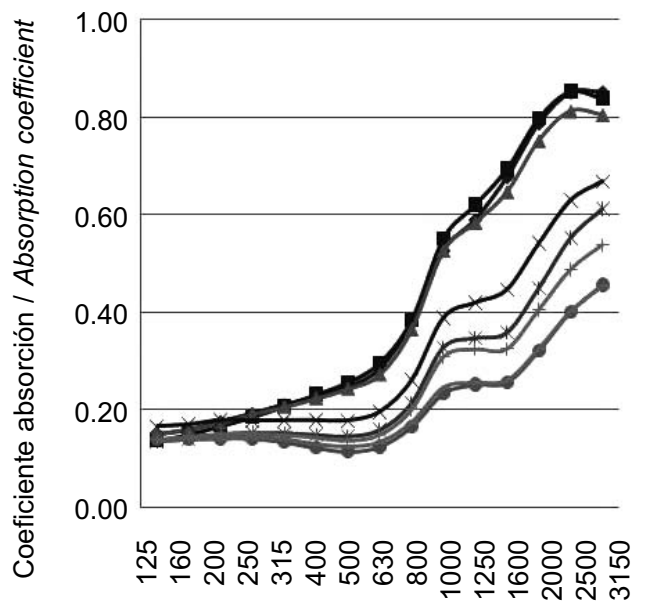

$\mathrm{f} / \mathrm{Hz})$

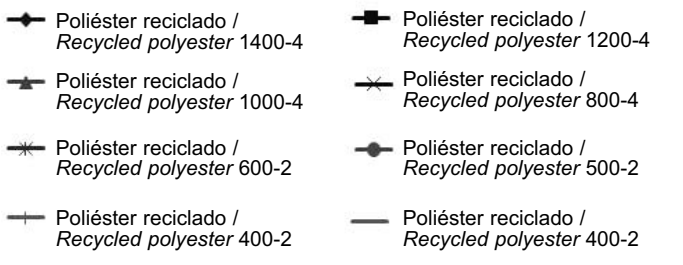

Figura 3. Coeficiente de absorción en incidencia normal para muestras de Poliester reciclado.

Figure 3. Absorption coefficient in normal incidence for samples of recycled polyester.

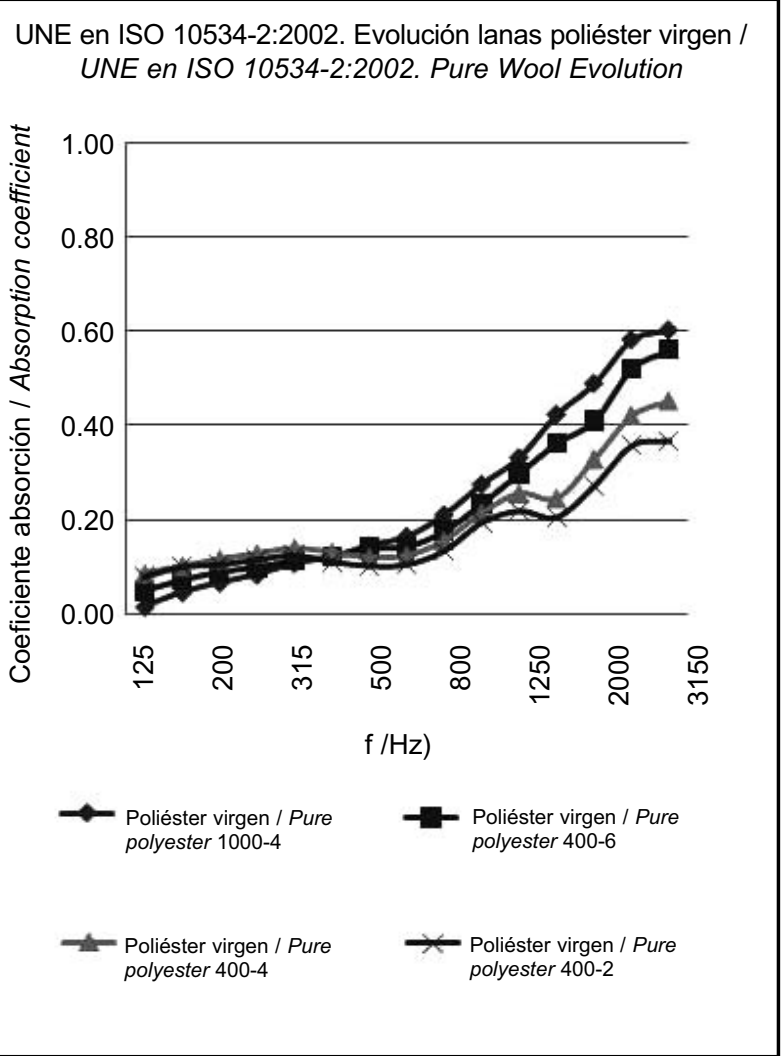

Figura 4. Coeficiente de absorción en incidencia normal para muestras de Poliéster Virgen.

Figure 4. Absorption coefficient in normal incidence for samples of Pure Polyester.

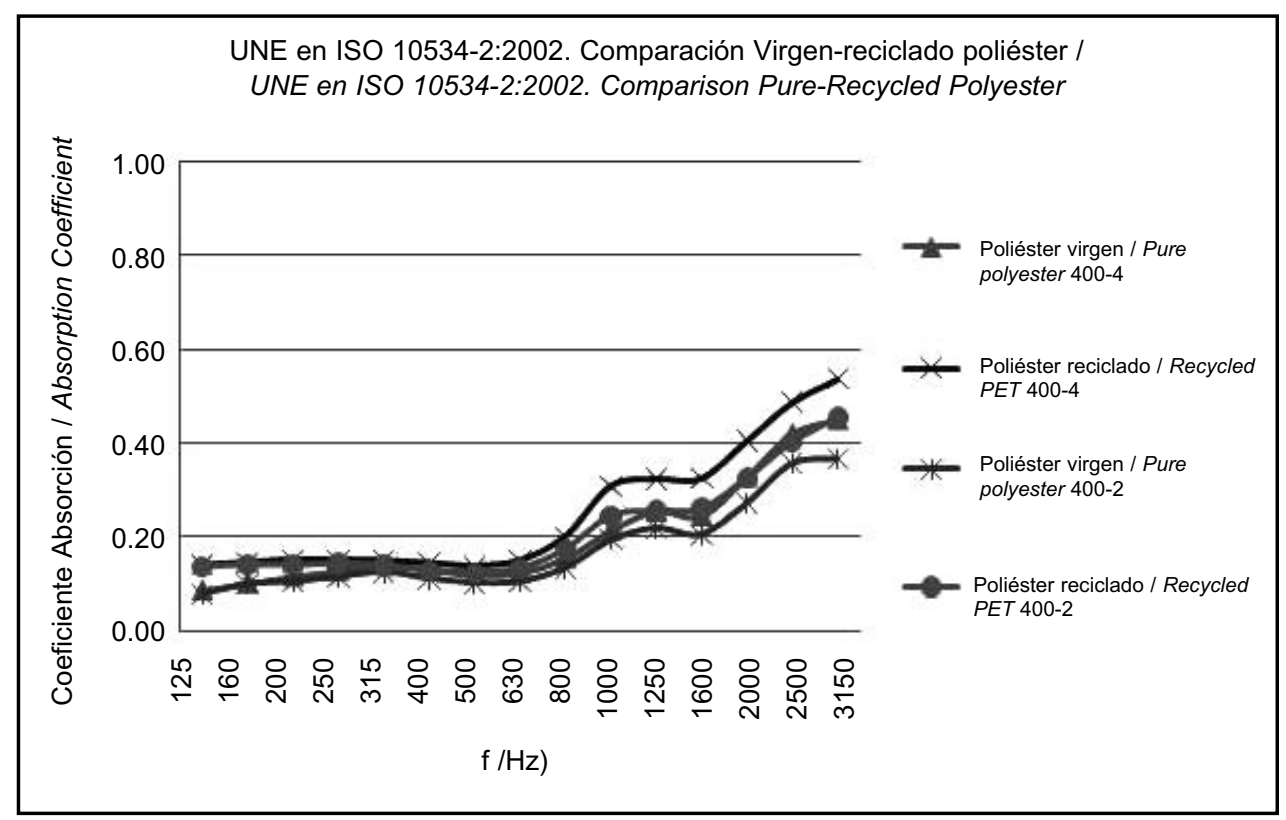

Figura 5. Coeficiente de absorción en incidencia normal. Comparación reciclado-virgen poliéster. Figure 5. Absorption coefficient in normal. Comparison Recycled-Pure Polyester. 


\subsection{Coeficiente de absorción en cámara reverberante}

En las Figuras 6, 7 y 8 podemos observar los valores del coeficiente de absorción sonora, obtenidos en cámara reverberante en función de la frecuencia, tal y como se ha realizado en el caso anterior.

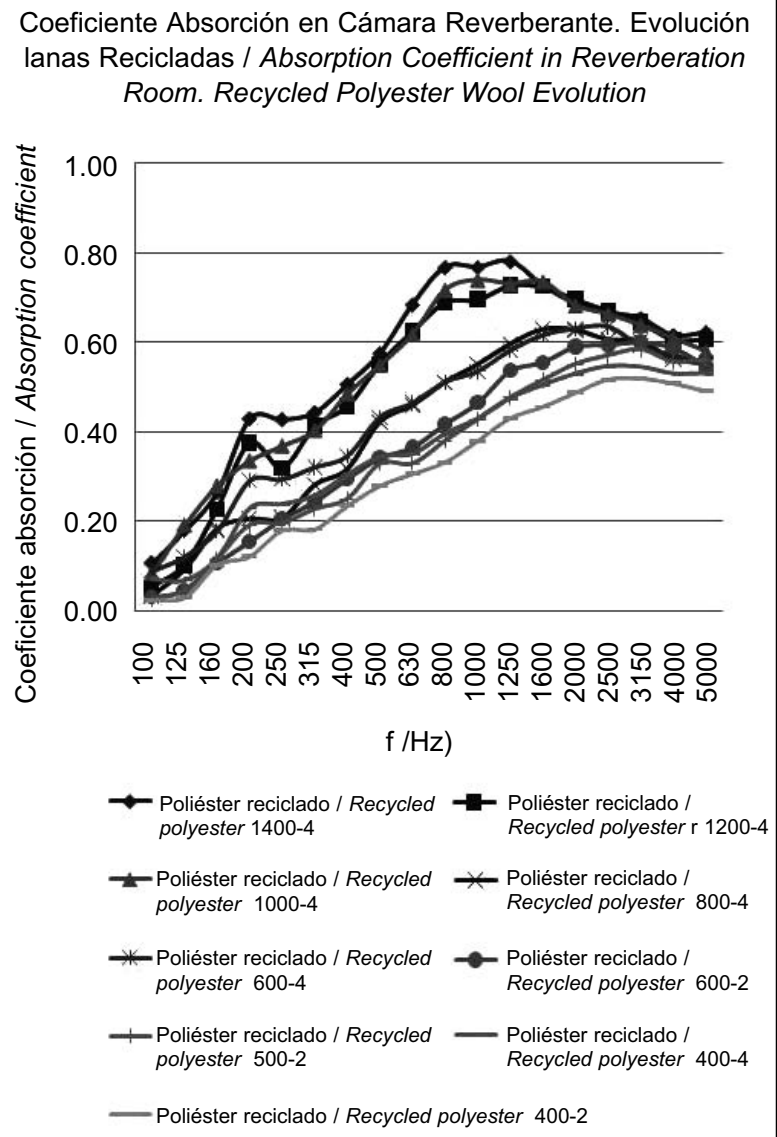

Figura 6. Coeficiente de absorción en cámara reverberante para muestras de PET.

Figure 6. Absorption coefficient in reverberation room for samples of PET.

\subsection{Absorption coefficient in reverberation room}

In Figures 6, 7 and 8 we can observe the values of sound absorption coefficient, obtained in the reverberation room depending on the frequency, as has been done in the previous case.

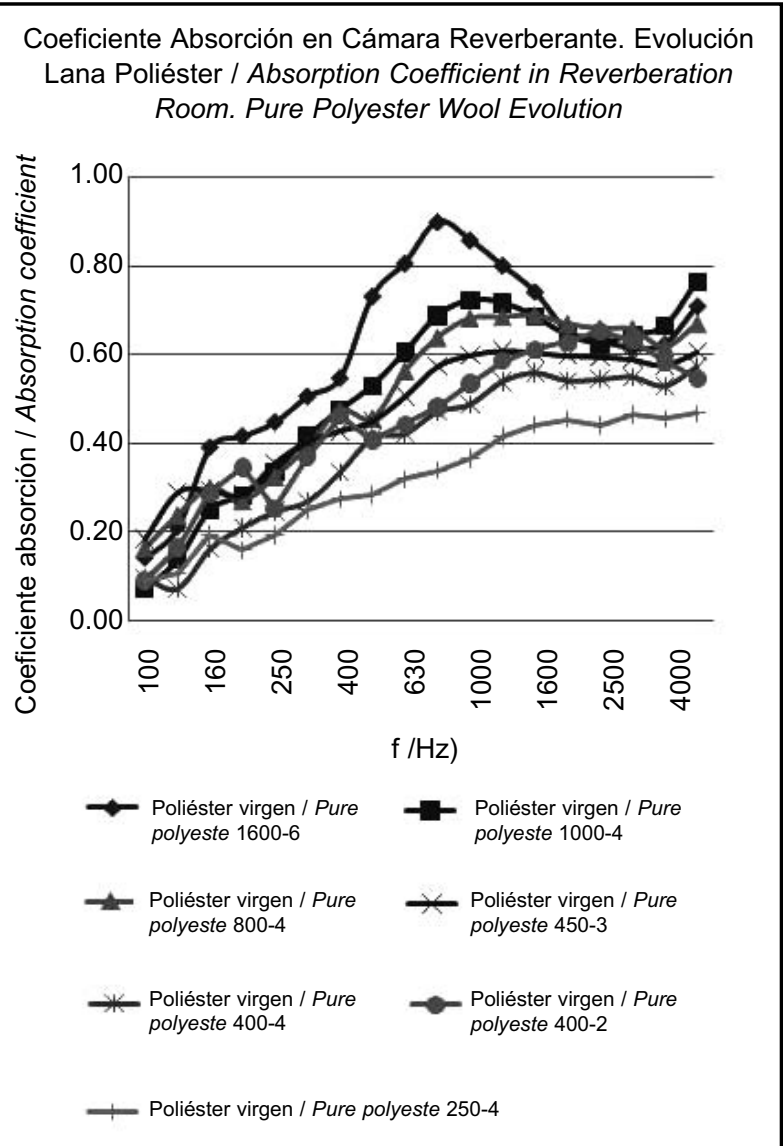

Figura 7. Coeficiente de absorción en cámara reverberante para muestras de Poliéster.

Figure 7. Absorption coefficient in reverberation room for samples of Polyester.

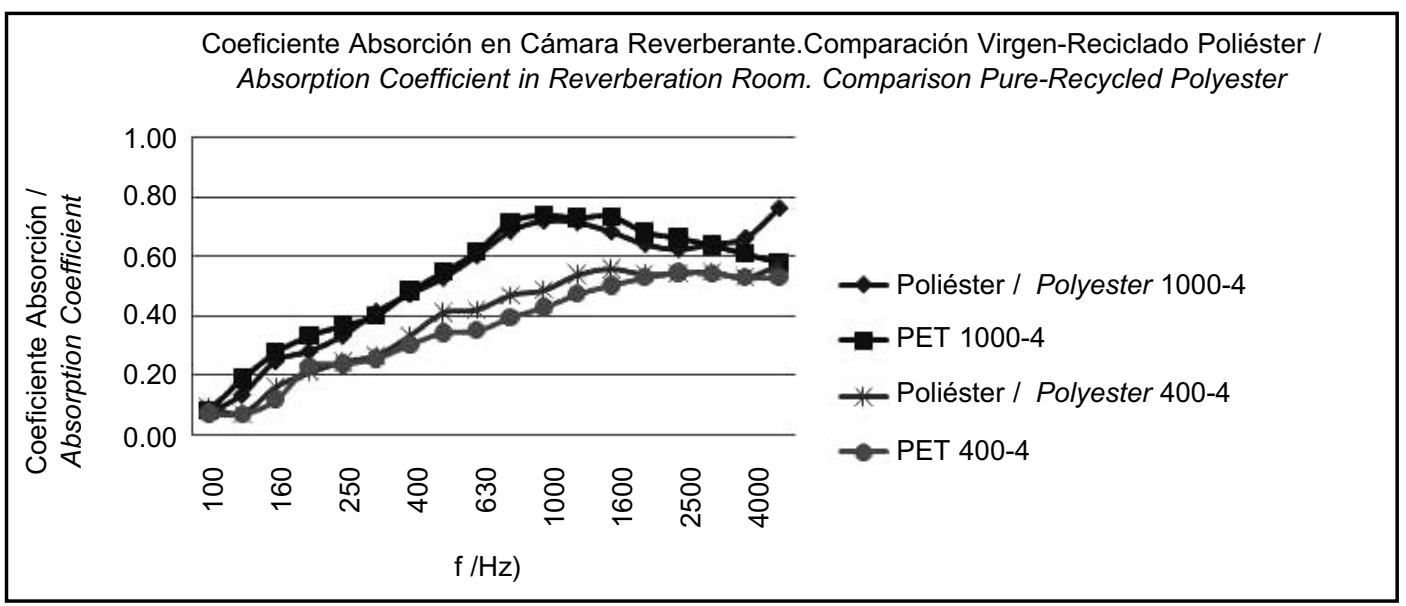

Figura 8. Coeficiente de absorción en cámara reverberante. Comparación PET-Poliéster.

Figure 8. Absorption coefficient in reverberation room. Comparison PET-Poliéster. 


\subsection{Coeficientes semi-empíricos}

En la Tabla 2 se observa el valor de los coeficientes semiempíricos propuestos por diferentes autores y los propuestos por el modelo en este trabajo desarrollado sobre lanas PET. Se presentan los proporcionados por Delany\&Bazley (14) para fibra de vidrio. Estos coeficientes son los que en la actualidad se toman como base para describir el comportamiento acústico de todo material fibroso (18). También se pueden observar los coeficientes propuestos por Garai\&Pompoli (15) para fibras de poliéster.

\subsection{Semi-empirical coefficients}

In Table 2 it is observed the value of the semi-empirical coefficients proposed by different authors and those proposed by the model developed about PET wool in this work. The models by Delany\&Bazley (14) for glass fibre are also presented. These coefficients are those which are currently taken as a basis to describe the acoustic behaviour of all fibrous material (18). We can also observe the coefficients proposed by Garai\&Pompoli (15) for polyester fibres.

Tabla 2 / Table 2

Valores de los ocho coeficientes que se han obtenido para el PET, comparados con los valores obtenidos por Delany\&Bazley y Pompoli\&Gara. Values of the eight coefficients were obtained for kenaf compared with values obtained by Delany and Bazley \& Pompoli \& Garai.

\begin{tabular}{|c|c|c|c|c|c|c|c|c|}
\hline Modelo / Model & C1 & C2 & C3 & C4 & C5 & C6 & C7 & C8 \\
\hline Delany\&Bazley & 0.057 & 0.754 & 0.087 & 0.732 & 0.189 & 0.595 & 0.098 & 0.700 \\
\hline Garai\&Pompoli & 0.078 & 0.623 & 0.074 & 0.660 & 0.159 & 0.571 & 0.121 & 0.530 \\
\hline PET & 0.078 & 0.648 & 0.082 & 0.602 & 0.156 & 0.629 & 0.108 & 0.506 \\
\hline
\end{tabular}

En las Figuras 9, 10 y 11 podemos observar valores del coeficiente de absorción en incidencia normal medido y valores predichos utilizando el modelo que describe las lanas de poliéster, modelo de Garai\&Pompoli y el modelo en este trabajo expuesto que define el comportamiento acústico de las lanas de reciclado de PET. Estas figuras muestran valores para muestras de $4 \mathrm{~cm}$ de espesor y 1200,1000 y $400 \mathrm{~g} / \mathrm{m}^{2}$ de densidad superficial, respectivamente.

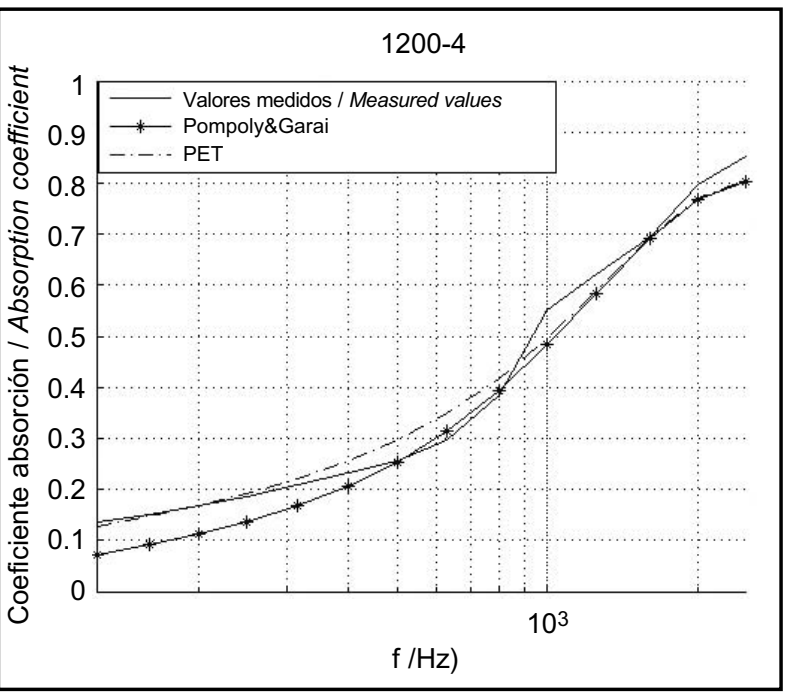

Figura 9. Coeficiente de absorción en incidencia normal; comparación entre valores medidos y valores predichos por diferentes modelos.

Figure 9. Absorption coefficient in normal incidence, comparison between measured and predicted values by different models.
In Figures 9, 10 and 11 we can see the values of the measured absorption coefficient in normal incidence and predicted values using the model that describes the poliéster wool, Garai\&Pompoli model and the model in the present work that defines the acoustic behaviour of the PET recycled wool. These figures show the values of samples of $4 \mathrm{~cm}$ of thickness and 1200, 1000 and $400 \mathrm{~g} / \mathrm{m}^{2}$ of superficial density, respectively.

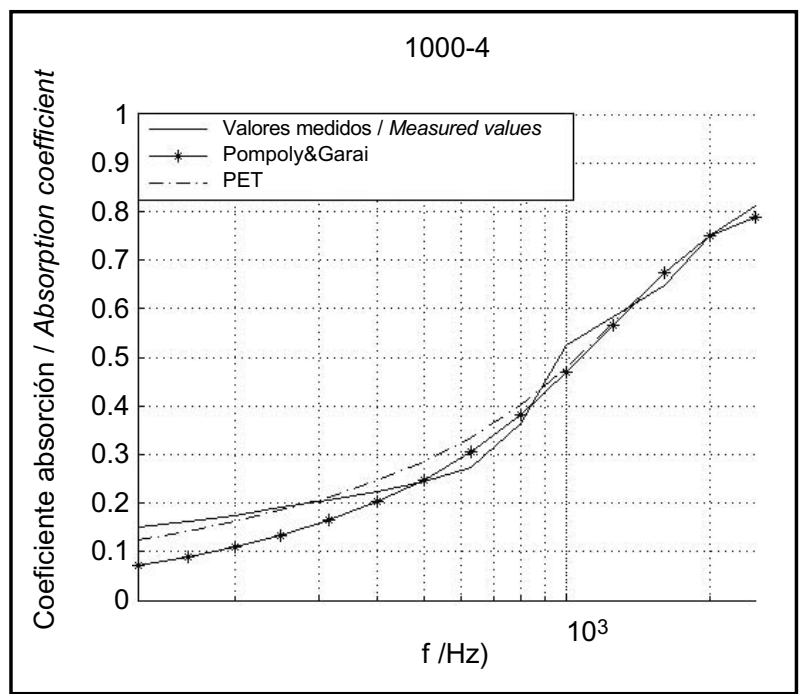

Figura 10. Coeficiente de absorción en incidencia normal; comparación entre valores medidos y valores predichos por diferentes modelos.

Figure 10. Absorption coefficient in normal incidence, comparison between measured and predicted values by different models. 


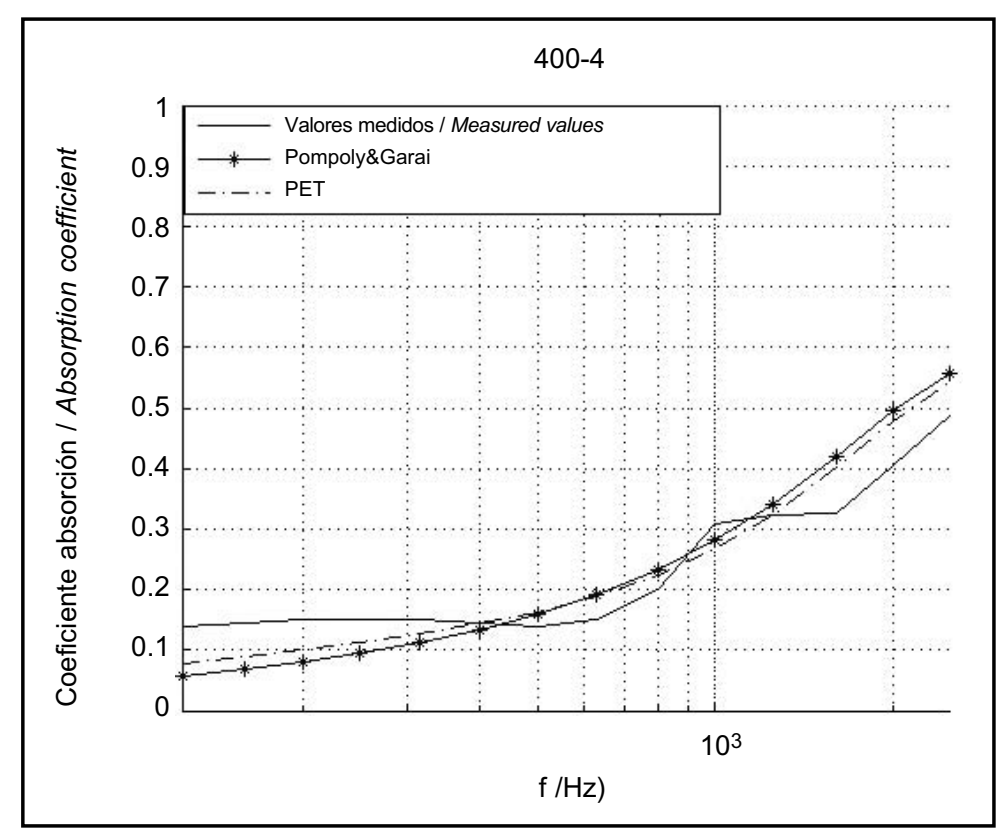

Figura 11. Coeficiente de absorción en incidencia normal; comparación entre valores medidos y valores predichos por diferentes modelos. Figure 11. Absorption coefficient in normal incidence, comparison between measured and predicted values by different models.

\section{CONCLUSIONES}

En primer lugar se puede observar cómo estos nuevos materiales presentan las características de un material absorbente acústico: esto se observa en el coeficiente de absorción en incidencia normal obtenido, éste aumenta al aumentar la frecuencia. Además, desde el punto de vista de la fabricación, se ha conseguido un material estable, utilizando exactamente la misma maquinaria y siguiendo la misma cadena de fabricación que para la elaboración de lanas de poliéster. El único cambio ha sido la materia prima, en este caso, proviene de reciclado de botellas de plástico.

También se ha podido observar que la evolución con la frecuencia del coeficiente de absorción en incidencia normal de las muestras de PET (poliéster reciclado) es prácticamente idéntica a la evolución con la frecuencia de las muestras de poliéster virgen. La misma conclusión se puede obtener de la evolución con la frecuencia de los coeficientes de absorción en cámara reverberante. Destacar que en la actualidad no se conservan muestras de poliéster virgen, por lo que no se puede asegurar que las densidades de éstas coincidan con las densidades de fabricación.

Por otro lado, desde el punto de vista teórico, la correlación entre los valores medidos en laboratorio y valores predichos, utilizando el modelo frecuencial (constante de propagación e impedancia acústica), con los coeficientes obtenidos en este trabajo es satisfactoria. El modelo de Delany\&Bazley (14) se ajusta a los valores experimentales

\section{CONCLUSIONS}

First of all, it can be observed how these new materials present characteristics of an absorbent acoustic material. This can be seen in the absoption coefficient in normal incidence obtained, since it increases as the frequency does. Furthermore, from the point of view of the manufacture, a stable material has been achieved using exactly the same machinery and following the process of the polyester wool. The only difference has been on the raw material, which this time comes from the recycling of plastic bottles, from their remnants.

It has also been noted that the evolution of the frequency of the absoption coefficient in normal incidence of the PET samples (recycled polyester) is nearly identical to the evolution of the frequency of the samples of pure polyester. We can come to the same conclusion with the evolution of the frequency of the absoption coefficients in a reverberant room. Nowadays there are no pure polyester samples kept, thus, the densities of the samples can't be said to coincide with the manufacture ones.

On the other hand, from a theoretical point of view, the correlation between the values measured in the laboratory and the predicted ones, using the frequency model (the propagation constant and acoustic impedance), with the obtained coefficients in this work is satisfactory. The model by Delany\&Bazley (14) adapts to 
en algunos materiales, como lana de roca. El modelo de Pompoli\&Garai (17) también se ajusta de forma satisfactoria a los valores experimentales para las fibras de poliéster. Se ha desarrollado un modelo para el reciclado de PET, que se ajusta a los valores experimentales. Destacar la similitud entre los coeficientes que se han obtenido para describir el comportamiento frecuencial de las lanas de PET y los coeficientes que Pompoli\&Garai obtienen para describir el comportamiento de materiales elaborados a partir de fibras de poliéster.

\section{AGRADECIMIENTOS}

Este trabajo ha sido financiado por el Ministerio de Educación y Ciencia. DG RESEARCH (BIA2007-C02-01 y BIA2007-C02-02) y por el Ministerio de Asuntos Exteriores y Cooperación, en el Programa de Cooperación Interuniversitaria e Investigación Científica (A/023748/09). the experimental values in some materials, such as rockwool. The model by Pompoli\&Garai (17) also matches the experimental values for the polyester fibres. It has been developed a model for the PET recycling that adapts to the experimental values. It is to be noted the similarity of the coefficients obtained to describe the frequency behaviuor of the PET wool and the coefficients that Pompoli\&Garai achieve to describe the behaviour of the materials manufactured out of polyester fibres.

\section{ACKNOWLEDGEMENTS}

This work has been funded by the Ministry of Education and Science, DG RESEARCH (BIA2007-C02-01 and BIA2007-C02-02) and by the Foreign Office, in the InterUniversity Cooperation and Scientific Research Programme (A/023748/09).

\section{BIBLIOGRAFÍA / BIBLIOGRAPHY}

(1) Alba, J.; Ramis J.; Redondo, J.; Sanchis, V.: "Aislamiento acústico a ruido aéreo con lanas textiles". CIATEA (2004), Gijón.

(2) Alba, J.; Ramis J.; Redondo, J.; Sanchis, V.: "Soluciones al ruido reverberante excesivo basadas en fibras de poliéster". IV Congreso Ibero-Americano de Acústica (2004), Guimaraes, Portugal.

(3) Real Decreto 1371/2007, de 19 de octubre, por el que se aprueba el Documento Básico "DB-HR Protección frente al ruido" del Código Técnico de la Edificación y se modifica el Real Decreto 314/2006, de 17 de marzo, por el que se aprueba el Código Técnico de la Edificación. (BOE 23-octubre-2007). Corrección de errores y erratas de la orden VIV/984/2009, de 15 de abril, por la que se modifican determinados documentos básicos del Código Técnico de la Edificación, aprobados por el Real Decreto 314/2006, de 17 de marzo, y el Real Decreto 1371/2007, de 19 de octubre. (BOE 23-septiembre-2009).

(4) Alba, J.; Ramis, J.; Redondo, J.; Sanchis, V.:"Aplicaciones acústicas de lanas textiles". IV Congreso Ibero-Americano de Acústica (2004), Guimaraes, Portugal.

(5) Alba, J.; Ramis, J.; Sanchis, V.: "Estudio de la potencia acústica producida por tubos flexibles con terminación en forma de codo". Tecniacústica (2005), Terrasa.

(6) Ramis, J.; Alba J.; del Rey, R.; Escuder, E.; Sanchís, V.; "Nuevos materiales absorbentes acústicos basados en fibras de kenaf", Mater. Construcc., vol 60, no 299, pp. 133-143 (2010). doi: 10.3989/mc.2010.50809.

(7) Navacerrada, M. A.; Díaz, C., Pedrero, A.; García, L. E.: "Absorción acústica de espumas de aluminio". Mater. Construcc., vol. 58, no 291 (2008).

(8) Lu, T. J.: Hess, A.; Ashby, M. F.: "Sound absorption in metallic foams", Journal of Appl. Phys., vol. 85 (1999), pp. $7528-7538$. http://dx.doi.org/10.1063/1.370550

(9) Voronina, N.: "Acoustic properties of fibrous materials". Appl. Acoust., vol. 42, pp 165-174 (1994). http://dx.doi.org/10.1016/0003$682 \times(94) 90005-1$

(10) UNE-EN ISO 10534-2: Acústica. "Determinación del coeficiente de absorción acústica y de la impedancia acústica en tubos de impedancia", parte 2, "Método de la función de transferencia" (ISO 10534-2:1998).

(11) Ingard, K. U.; Dear, T. A.: "Measurement of Acoustic Flow Resistance". Journal of sound and Vibration, 103 (1985), pp. 567-572. http://dx.doi.org/10.1016/S0022-460X(85)80024-9

(12) UNE-EN 29053.1994. Acústica. Materiales para aplicaciones acústicas. Determinación de la resistencia al flujo de aire (ISO9053:1991).

(13) UNE-EN ISO 354:2004. Acústica. Medición de la absorción acústica en una cámara reverberante. (ISO 354:2003).

(14) Delany, M. E.; Bazley, E. N.: "Acoustical Properties of Fibrous Absorbent Materials", Appl. Acoust. 3 (1970), pp. $105-116$. http://dx.doi.org/10.1016/0003-682X(70)90031-9

(15) Miki, Y.: "Acoustical Properties of Porous Materials-Generalitations of empirical models", Journal of the Acoustical Society Jpn (E) 11,1 (1990), pp 13-24.

(16) Dunn, P.; Davern, W. A.: "Calculation of acoustic impedance of multi-layer absorbers", Applied Acoustics, 19 (1986), pp. $321-334$. http://dx.doi.org/10.1016/0003-682X(86)90044-7 
(17) Garai, M.; Pompoli, F.: "A simple empirical model of polyester fibre materials for acoustical applications", Appl. Acoust. 66 (2005), pp. 1383-1398. http://dx.doi.org/10.1016/j.apacoust.2005.04.008

(18) UNE-EN 12354-6:2004: Acústica en la edificación. "Estimación de las características de las edificaciones a partir de las características de sus elementos", parte 6, "Absorción sonora en espacios cerrados". 